\title{
CURRENT PERSPECTIVES IN CORRECTIONS: A CACOPHONY
}

\author{
Herbert S. Miller*
}

\section{INTRODUCTION}

Cesare Beccaria, commonly considered to be the father of modern criminology, ${ }^{1}$ stated his belief over two hundred years ago that "crimes are only to be measured by the injury done to society,"2 and that the severity of punishment should be proportionate to the seriousness of the crime. ${ }^{3}$ Arguing that the aim of punishment should be prevention and deterrence, ${ }^{4}$ Beccaria proposed that it should make a strong and lasting impression on others, but involve minimal physical injury to the offender. "Punishment may not be an act of violence of one, or of many, against a private member of society; it should be public, immediate and necessary; the least possible in the case; proportioned to the crime, and determined by the laws." 6

More than one hundred years later another criminologist, Enrico Ferri, listed what he thought were the anthropological, physical, and social causes of crime: 1) the social environment, such as the density of population; 2) conditions of race, age, and sex; 3) the economic and political organization of society; 4) domicile and social class; 5) climate, nature of the soil, succession of day and night and seasons, the annual temperature, atmospheric conditions, and agricultural production; 6) the educational system and religious opinion; and 7) the administrative, judicial, penal, legislative, law enforcement, and bureaucratic structure. $^{7}$

On the basis of these factors, Ferri concluded that penalties should fit the individual, not the offense, ${ }^{8}$ a position that sharply contrasts with that taken by Beccaria. These issues-whether punishment should fit the crime or the individual, and indeed what its purpose is-are debated to this very day.

\footnotetext{
* Co-director, Institute of Criminal Law and Procedure, Georgetown University Law Center, and Chairman. ABA Joint Committee on the Legal Status of Prisoners.

1. N. Kittrie, The Right to Be Different 20-21 (1971).

2. C. Beccaria, Essay on Crimes and Punishments 33 (2d ed. Philadelphia 1819).

3. Id. at 28 .

4. Id. at 47 .

5. Id.

6. Id. at 160 .

7. E. Ferri, Criminal Sociology $186-87$ (Boston 1917). The first edition of this book appeared in 1884 .

8. Id. at VI-VII (Introduction). "Thus the great truth of the present and the future, for criminal science, is the individualization of penal treatment, for that Man, and for the cause of that Man's crime,"
} 
This article will discuss these conflicting views of crime and punishment as reflected both in recent proposed penal codes and current literature, changing assumptions concerning human nature, and how these changing assumptions have affected sentencing and correctional policies and their implementation in the United States. The author will question our present and future ability to contend with problems of deviance, whether through the criminal justice system or other modes reflecting our understanding of the causes of crime.

\section{Historical BACKGROUND}

The history of corrections has been characterized by one authority as "a graveyard of abandoned fads." 9 One such fad was the form punishment took in the eighteenth century, when Beccaria's call for "the least torment to the body of the criminal" " was still ignored. Actual punishment commonly took the forms of corporal punishment, exile, and execution. ${ }^{11}$ Indeed, it was in reaction to the barbaric codes of corporal punishment, mutilation, and degradation which had been in vogue throughout the American colonies that in April 1790 Pennsylvania passed what is widely regarded as the law that conceived the modern American prison administration system. ${ }^{12}$ Prisons appeared more humane, and indeed came to be regarded as a primary tool for "curing" offenders. David Rothman writes: ${ }^{13}$

Convinced that deviancy was primarily the result of the corruptions pervading the community, and that organizations like the family and the church were not counterbalancing them, [correctional reformers] believed that a setting which removed the offender from all temptations and substituted a steady and regular regimen would reform him. Since the convict was not inherently depraved, but the victim of an upbringing that had failed to provide protection against the vices at loose in society, a well-ordered institution could successfully re-educate and rehabilitate him. The penitentiary, free of corruptions and dedicated to the proper training of the inmate, would inculcate the discipline that negligent parents, evil companions, taverns, houses of prostitution, theatres, and gambling halls had destroyed. Just as the criminal's environment had led him into crime, the institutional environment would lead him out of it.

This analysis of the origin of crime became the theoretical foundation of the American prison system.

Another authority, Anthony Platt, has traced the development of the reformatory system for juveniles since the middle of the nineteenth century.

9. Martinson, Califormia Research at the Crossroads, 22 Crime \& Delinquency 180-81 (1976).

10. C. Beccaria, supra note 2.

11. L. Empey, Alternatives to Incarceration 1 (1967).

12. U.S. Dep't of Justice, The Attorney General's Survey of Release Procedures, Prisons V, 1 (1940).

13. D. Rothman, The Discovery of the Asylum $82-83$ (1971). 
This system reflected the popular belief that institutions could transform delinquents into law-abiding citizens. ${ }^{14}$ Prison discipline for adolescents and young adults was distinguished from that practiced in the traditional penitentiary by its foundation in indeterminate sentencing and "organized persuasion" rather than "coercive restraint." It was assumed that abnormal and troublesome individuals could be trained in such an environment to become useful and productive citizens.

Fundamental to most new institutions, whether for juveniles or adults, was the perceived relationship between punitive measures and reformation of criminals. Prevailing concepts of deviancy put a premium on rigorous discipline. Authorities were confident that the deviant could be taught discipline in a properly arranged environment, and they agreed that prison life had to be strict and unrelenting. Prison discipline was designed to induce the convict not merely to form good resolutions but also to support himself by honest industry. ${ }^{15}$

Throughout the last half of the nineteenth century there was a continuous debate between the so-called Pennsylvania and Auburn schools. ${ }^{16}$ The Pennsylvania adherents believed that work should be accomplished in complete isolation, and consequently they permitted no communication within the prison. Communication, it was felt, encouraged friendships between inmates, making it more likely that they would influence one another while in jail, as well as meet after release to resume a life of crime.

On the other hand, the Auburn advocates, operating on the principle that it was unnatural to prohibit any kind of communication between the prisoners, maintained them in separate cells at night but allowed them to work together during the day.

Both schools believed that prisons should be completely separate from the community, a logical outgrowth of their mutual feeling that the origins of crime lay in the larger vices of the community.

A National Congress on Penitentiary and Reformatory Discipline convened in 1870 and adopted the Principles of Prison Discipline, ${ }^{17}$ which emphasized reformation of imprisoned offenders, provided that both prisoners and prison officials accepted and believed in such reformation. The hostility of prisoners toward society was recognized, but the prevailing view was that the interest of society and the interest of the criminal were identical. That there was hostility between custodians and prisoners was also recognized. "It would be otherwise if criminals, on conviction, instead of being cast off, were

14. A. Platt, The Child (S)avers 46-47 (1969).

15. D. Rothman, supra note 13 , at 102 .

16. R. Goldfarb \& L. Singer, After Conviction 28-37 (1973).

17. Transactions of the Nat'l Congress on Penitentiary and Reformatory Discipline, Cincinati, Оhio, Остовer 12-18, 1870, at 541 (1971). 
rather made objects of a generous parental care; that is if they were trained to virtue, and not merely sentenced to suffering." 18 This was to be accomplished with minimal physical force, and

organized persuasion be made to take the place of coercive restraint, the object being to make upright and industrious freemen, rather than orderly and obedient prisoners. Brute force may make good prisoners; moral training alone will make good citizens; to the latter of these ends, the living soul must be won; to the former, only the inert and obedient body. ${ }^{19}$

The Principles also called for the replacement of peremptory sentences by those of indeterminate length measured by satisfactory proof of reformation rather than by the mere lapse of time. "Reformation is a work of time; and a benevolent regard for the good of the criminal himself, as well as for the protection of society, requires that his sentence be long enough for reformatory processes to take effect." ${ }^{20}$ Disparity in sentencing was not uncommon at that time. The "present extraordinary inequality of sentences for the same or similar crimes is a source of constant irritation among prisoners and the discipline of our prisons suffers in consequence." 21

The Principles emphasized education as a vital force in the reformation of "fallen men and women." 22 Industrial training was considered to be not only a means of improving character but a means of support as well. ${ }^{23}$ The contract system of prison labor was condemned as prejudical to discipline, finance, and the reformation of the prisoner, and as sometimes injurious to the interest of the free laborer. ${ }^{24}$ One principle stressed the importance of the prisoner's self-respect, and condemned the studied imposition of degradation as part of punishment because it destroyed aspirations, "crush[ed] the weak, irritat[ed] the strong, and indispos[ed] all to submission and reform." 25

In addition the Principles called for the classification or grading of prisoners so that separate prisons could be provided for the untried, for the incorrigible and for others of depraved character, as well as for women and younger criminals. ${ }^{26}$ Finally, the Principles recommended the establishment of preventive institutions such as truant homes and industrial schools for juveniles with potential criminal tendencies. ${ }^{27}$

The Principles of 1870 were based on assumptions which continue to dominate much of the thinking concerning the role of corrections in crime

18. Id. at 542

19. Id. at 543

20. Id. at 543 .

21. Id. at 545 .

22. Id. at 542 .

23. Id at 543 .

24. Id. at 543 .

25. Id. at 542 .

26. Id at 543 .

27. Id . at 544 . 
control. The major assumption was that the correctional system, including prisons and reformatories, could be a catalyst for rehabilitation. It is interesting to note that, in a major departure from the Pennsylvania and Auburn approaches, "organized persuasion" rather than "coercive restraint" was to be used in the treatment of prisoners.

In 1970 the American Correctional Association adopted a new Declaration of Principles which tracks some of the key concepts enunciated a hundred years earlier. ${ }^{28}$ The 1970 Declaration reaffirms reformation as a major goal of corrections. No correctional system should deprive an offender of the hope and possibility of ultimate return to full membership in society. The aim of the correctional process should be "the reintegration of the offender into society as a law-abiding citizen." 29

One principle reasserts the need for indeterminate sentencing in a correctionally-oriented system of crime control. " $[\mathrm{M}]$ aximum flexibility in the determination of [an] appropriate release date can assure the optimal benefits of correctional treatment." ${ }^{30}$ A caveat about inequality of sentences warns that "[t]he sentence should . . be commensurate with the seriousness of the offense and the extent of the offender's participation."31 "On the other hand, the length of the correctional treatment given the offender for the purposes of rehabilitation depends on the circumstances and character of the particular offender and may have little relationship to the seriousness of the crime committed." 32

Another principle echoes the 1870 recommendation that employable offenders be given the opportunity to engage in productive work without being exploited, as long as their labor does not unduly interfere with free enterprise. ${ }^{33}$ It calls upon government, industry, and labor to cooperate fully in the establishment of productive work programs "with a view to imparting acceptable skills, work habits, and attitudes conducive to later gainful employment."34

The need for diversification of correctional efforts in order to meet the "varying needs of the offenders" is reiterated. ${ }^{35}$ Once again the establishment of educational programs, improvement of vocational confidence and skills, and the provision of meaningful knowledge about the world and society "to assure the eventual restoration of the offender as an economically self-

28. ABa Comm'n on Correctional Facilities and Services, and Council of State Governments, Compendium of Model. Correctional Legislation and Standards X-75 (1972).

29. Id. at $\mathrm{X}-76$.

30. Id. at $\mathrm{X}-75$.

31. Id.

32. Id.

33. Id. at $\mathrm{X}-77$.

34. Id.

35. Id. at $\times-76$. 
sustaining member of the community" are all encouraged. ${ }^{36}$

In a major addition to Principles of 1870 , community-based corrections are emphasized in the 1970 Declaration.$^{37}$ Probation, parole, halfway houses, and work and study furlough programs are stressed. Importance is given to "conditional freedom," "parole supervision," "the needs of the individual," and the fact that "participants should be carefully selected and supervised."38

Finally, the Declaration calls for public support and explicitly states that "correction and punishment are the presently recognized methods of preventing and controlling crime or delinquency. Strengthening and expansion of the correctional methods should generally be the accepted goal." 39

The Principles of 1870 and the Declaration of 1970 both assume that correction is a major factor in preventing and controlling crime. This assumption is shared by many sophisticated professional groups who have also expected brilliant results from the corrections system. In addition, despite widespread recognition of the failure of prisons to rehabilitate, there is also a continuing assumption that under the right circumstances prisons can rehabilitate. This is reflected in the shifting focus of attention of some experts in recent years from the crime itself to the psychological dynamics of the criminal mind. ${ }^{40}$ In order to facilitate rehabilitation, wardens may now be in charge of individual treatment, supplementing the work of their colleagues responsible for custody or mass treatment.

The rationale behind this approach has been ably explained by United States Supreme Court Chief Justice Warren Burger: ${ }^{41}$

When a sheriff or a marshall takes a man from a courthouse in a prison van and transports him to confinement for two or three or ten years, this is our act. We have tolled the bell for him and whether we like it or not, we have made him our collective responsibility. We are free to do something about him; he is not.

\section{Current Issues}

\section{A. Rehabilitation and Reformation}

The controversy surrounding rehabilitation has been partly reflected in the various proposed corrections codes of the last decade or so. They have

36. Id.

37. Id.

38. Id.

39. Id. at $\mathrm{X}-75$

40. Killinger, Problems and Guidelines in the Rehabilitation of the Offender, in MoBILIzING Resources Toward the Rehabilitation of the Offender, Proceedings of the Saratoga Conference 13-14 (March 19-21. 1963) (sponsored by New York State Department of Mental Hygiene and U.S. Public Health Service, National Institute of Mental Health).

41. New York State Special Comm'n on Attica. The Official Report of the New York State Special Comm'n on Attica XiV (1972). 
embodied a mix of goals encompassing crime prevention, punishment, rehabilitation, protection of society, deterrence, and the assurance of public safety. Some reflect a multifaceted view of corrections by adopting several often contradictory goals in the same phrase. For example, the 1971 proposed code of the National Commission on Reform of Federal Criminal Laws aimed at all of the above objectives, including "the rehabilitation of those convicted of violations of this Code." 42 It also called for penalties "which are proportionate to the seriousness of offenses and which permit recognition of differences in rehabilitation possibilities among individual offenders." 43

In 1971 the Advisory Commission on Intergovernmental Relations portrayed upgraded corrections as "essential to the reduction of crime" through "efforts to rehabilitate and restore criminal offenders as law-abiding productive members of society." 44 Diversified programs were declared necessary to "facilitate individualized treatment." ${ }^{45}$ It proposed a model corrections act. ${ }^{46}$

The purpose of this act is to establish an agency of state government to provide for the custody, care, discipline, training, treatment, and study of persons committed to state correctional institutions or on probation or parole, and to supervise and assist in the treatment, training and study of persons in local correctional and detention facilities, so that such persons may be prepared for release, aftercare, and supervision in the community.

The National Council on Crime and Delinquency subsequently added to this list of aims in its model sentencing act. ${ }^{47}$

The purpose of penal codes and sentencing is public protection. Sentences should not be based upon revenge and retribution. The policy of this act is that dangerous offenders shall be identified, segregated and correctively treated in custody for long terms as needed, and that other offenders may be committed for a limited period. Non-dangerous offenders shall be dealt with by probation, suspended sentences, or fine, wherever it appears that such disposition does not pose a danger of serious harm to public safety.

Persons convicted of crime shall be dealt with in accordance with their potential for rehabilitation, considering their individual characteristics, circumstances and needs.

These and other proposed codes assume that, with adequate resources, correctional authorities have the ability to analyze and diagnose offenders, correct their behavior, and assure their functioning in society as productive law-abiding citizens. The 1962 Model Penal Code is explicit in its recognition of "accepted scientific methods and knowledge in the sentencing and treatment of offenders." 48 The American Correctional Association believes that

42. Nat'l Comm'n on Reform of Federal Criminal Laws, Final Reportr 2 (1971).

43. Id.

44. Advisory Comm on Intergovernmental Relations, Correctional Reform 6 (1971).

45. Id.

46. Id.

47. Nat'l Council on Crime and Delinquency, Model Sentencing ACt $\$ 1$ (1972). 
corrections, properly funded with trained personnel, can act as a basic source of crime control, prevention, and reduction. ${ }^{49}$ The ABA asserts that correctional treatment can be most effectively provided by total confinement in certain cases. ${ }^{50}$

However, there is not a consensus among experts on the desirability or viability of rehabilitation at the present time. In his classic work The Borderland of Criminal Justice, Francis Allen analyzed the debasement of the rehabilitative ideal that occurs when the language of therapy is employed to disguise the reality of corrections. ${ }^{51} \mathrm{He}$ pointed out that the indeterminate sentence has resulted in generally longer periods of imprisonment. ${ }^{52}$ Moreover, he indicated that the values of a free society may be threatened by the rehabilitative approach. "[T]he values of individual liberty may be imperiled by claims to knowledge and therapeutic techniques that we, in fact, do not possess and by our failure to concede candidly what we do not know. ${ }^{53}$

William E. Amos, a former Chairman of the Youth Corrections Division of the United States Board of Parole, has stated his belief that fewer people should be confined, and that the philosopy of confinement should be deterrence, accountability, and the protection of society-not rehabilitation. ${ }^{54}$

Judge Marvin Frankel in 1973 criticized the rehabilitative ideal as genetically flawed because of its assumption that criminals are sick. Society should face the real reason we imprison individuals. ${ }^{55}$

However we prettify them, by aspirations to redeem and regenerate and whatever may come to pass someday, criminal penalties are painful measures taken against offenders for punishment. Indeed, moral philosophers of stature have insisted that in the last analysis no other justification for criminal sanctions exists. We need not vote on that position to know what evervone knows-that we find and jail and denounce people to punish them.

A more extreme view is taken by the American Friends Service Committee in its 1971 analysis of the evils of discretion in the criminal justice system. ${ }^{56}$ This analysis notes that proposed reforms follow traditional lines of more and better personnel, more programs, and more money. ${ }^{5 i}$ The Committee attacks

48. Model Prnal Code $\$ 1.02$ (Prop. Offcial Draft. 1962). Few authorities today would agree that our methods and knowledge about offenders have generally accepted scientific validity.

49. See generally ABA Comin on Correctional Facilities and Services. and Council of State Governments, supra note 28.

50. Aba Project on Standards for Criminal Justice, Standards Relating to Sentencing Alternatives and Procedures $\$ 2.5$ (c) (App. draft 1968).

51. F. Allen, The Borderland of Criminal Justice 32-35 (1964).

52. Id. at 34-35.

53. Id. at 37 .

54. Amos, The Philosophy of Corrections: Revisited, 38 Fed. Probation No. 1, at 43. 46 (1974).

55. M. Frankel, Criminal Sentences 111 - 12 (1973).

56. American friends Service Comm., Struggle for Justice. A Report on Crime and Punishment in America (1971).

57. Id. at 11 
the premise of such an approach, namely that rehabilitative programs are on the right track but have never been given a fair trial. The Committee believes that expectations of obtaining the resources required for such reform are unrealistic. ${ }^{58}$ But the heart of the attack is aimed at the system: ${ }^{59}$

We have grave doubts that the successful implementation of the kinds of reform proposed would serve legitimate public interests or alleviate the major abuses of our present programs. This concern arises from compelling evidence that the individualized treatment model, the ideal toward which reformers have been urging us for at least a century, is theoretically faulty, systematically discriminatory in administration, and inconsistent with some of our most basic concepts of justice.

In 1974, Robert Martinson analyzed numerous correction programs and approaches and found that with few exceptions they had all failed to significantly reduce recidivism rates. He felt it was possible that some worked but that our research is so bad there is no way of knowing. ${ }^{60}$

Having entered this very serious caveat, I am bound to say that these data, involving over two hundred studies and hundreds of thousands of individuals as they do, are the best available and give us very little reason to hope that we have in fact found a sure way of reducing recidivism through rehabilitation. This is not to say that we found no instances of success or partial success; it is only to say that these instances have been isolated, producing no clear pattern to indicate the efficacy of any particular method of treatment. And neither is this to say that factors ontside the realm of rehabilitation may not be working to reduce recidivism-factors such as the tendency for recidivism to be lower in offenders over the age of 30 ; it is only to say that such factors seem to have little connection with any of the treatment methods now at our disposal.

Martinson criticizes the notion that programs do not work due to inadequate resources, citing radical flaws in rehabilitative strategies. Education or psychotherapy at their best cannot overcome or reduce the powerful tendency for offenders to continue criminal behavior and, according to Martinson, criminals are not necessarily sick. ${ }^{61}$ Approaches emphasizing rehabilitation overlook and even deny "the normality of crime in society and the personal normality of a very large proportion of offenders, criminals who are merely responding to the facts and conditions of our society." ${ }_{22}$ Martinson discusses alternative approaches but comes to no conclusion as to which may be valid.

\section{B. Sentencing}

Another key point of discussion among authorities in the corrections field is the most desirable approach to sentencing. As already noted, replacement

\footnotetext{
58. $I d$.

59. Id. at 12 .

60. Martinson, What Works? Questions and Answers About Prison Reform, 35 Pub. INTEREST 22, 49 (Spring 1974).

61. Id.

62. Id.
} 
of peremptory sentencing by indeterminate sentencing was recommended by both the 1870 and 1970 Declarations. Until recently, indeterminate sentencing was believed to allow more careful consideration of each offender's rehabilitation potential to enter into the sentencing decision. Indeed, the assumption that rehabilitation is a realistic goal has persistently been accompanied by the argument that discretion should be exercised for the benefit of the offender. But the logical outgrowth of individualized treatment and rehabilitation-the need for almost total discretion-has resulted in almost total power over the offender. One key to this control has been the indeterminate sentence with release conditioned upon participation by the offender in prescribed treatment programs.

Accordingly, some observers have begun to question the assumptions and methods of the treatment practitioners. The treatment philosophy has been held directly responsible for the destructive, unchecked growth of arbitrary and lawless power that a few persons have had over the convict and over the length of sentences, all in the name of rehabilitation. This unchecked power is regarded by many as the basis for the psychological brutality of modern prison life. ${ }^{63}$

The sentencing structure in the federal government and most states has given judges disrection to impose a basically indeterminate sentence without effective review or accountability. ${ }^{64}$ This arrangement has been described by Judge Marvin Frankel as "terrifying and intolerable for a society that professes devotion to the rule of law." ${ }^{55}$ In his view it has led to sentencing disparities stemming from unpredictable variables embodied in the occupants of the trial benches. ${ }^{66}$

Frankel's solution is shorter prison sentences and increased use of alternatives to prison, such as probation, work release, halfway houses, and fines. ${ }^{67}$ Judicial sentencing discretion could be modified; sentencing institutes for judges could be held and sentencing councils established; mixed tribunals of three (judge, behavioral scientist, and social scientist or educator) would sentence; and there would be appellate review of sentences. ${ }^{68}$ Sentences should be stated with certainty based upon factors known on the day of sentencing. ${ }^{69}$ Several federal judges have likewise called for a reassessment of indetermi-

63. See, e.g., Coleman, Prisons, the Crime of Treatment 11 Psychiatric Opinion no. 3, at 5 (1974).

64. See aba Commin on Correctional. Facilities and Services, Sentencing Computation Laws and Practice (1974).

65. M. Frankel, supra note 55 , at 5 .

66. Id. at 6 .

67. Id. at 58-59.

68. Id. at 61-85.

69. Id. at 101 . 
nate sentencing-one characterizing it as being frequently "evil and unwarranted." "7"

In 1971 the American Friends Service Committee Report which attacked traditional penal reforms as unrealistic also recommended the elimination of discretion. ${ }^{71}$ In the ideal model, according to the Report, money bail would be eliminated; all offenders would be released except where strong evidence indicated possible commission of further violent crimes; speedy trials would be required; plea bargaining would be abolished and all felony cases tried; the crime would determine the punishment. There would be no discretion in setting sentences, no indeterminate sentences, and unsupervised street release would replace parole. ${ }^{72}$

Since initial sentencing decisions are usually made by judges, judicial idiosyncrasies as well as the system itself have been subject to examination. At least one study looked at comparative sentencing practices between judges and found what appears to be an irrational pattern of disparities. ${ }^{73} \mathrm{~A}$ study conducted in Canada with the cooperation of the judges involved was one of the few which has attempted to penetrate beyond a surface analysis of the actual sentences imposed. ${ }^{74}$ This Canadian study examined judicial background characteristics to determine whether they affected attitudes towards sentencing. Five basic attitudes were discerned: 1) "just deserts"-punishment should be proportionate to the severity of the crime; 2) "punishment corrects"-punishment should prevent further crime by the offender; 3) "intolerance"-punishment should correct evil, immorality and sin; 4) "social defense"-punishment should serve as a general deterrent; and 5) "modernism"-attitude towards failure. ${ }^{75}$ Variation in sentencing was directly related to variations in attitudes, thus making it appear that "justice is a very personal thing." 76

Finally, the study specifically found that these attitudes predispose judges to respond in particular ways to certain types of crime, depending on how they define the world and their relationship to it. In short, their response is molded by the social environment in which they live, an environment of facts, laws, ideas, and people. The study concluded: "Sentencing is not a rational,

\footnotetext{
70. See, e.g., id.

71. American Friends Service Comm., supra note 56, at 124-44.

72. Id. at $143-44$.

73. A. Partridge \& W. Eldridge, The Second Circuit Sentencing Study (1974). This is an excellent study which looked at the record of sentence imposed by the judges in that circuit for a variety of crimes. The study found little unanimity, little consistency, and no discernable pattern which could explain the great variation in relative severity which almost all the judges exhibited.

74. J. Hogarth. Sentencing as a Human Process (1971). See also W. Gaylin, Partial Justice (1974) for an in depth study of bias in sentencing.

75. J. HogakTH, supra note 74 , at 361-62.

76. Id. at 365 .
} 
mechanical process. It is a human process and is subject to all the frailties of the human mind." 77

The Twentieth Century Fund Task Force Report characterizes sentencing disparities as unfair, stating that unless they are drastically reduced the criminal justice system will suffer increasing loss of respect and credibility from both those who obey and those who violate the law. ${ }^{78}$ The current structure results in disparities because of the absence of criteria for both judges and parole boards-a consequence of the individualized sentencing approach endemic to the United States. ${ }^{79}$ The Report asserts that it is possible to construct and implement a just sentencing system which is more effective in terms of reducing crime. To do this, the system must impose specific, appropriate punishments and distribute them equitably. ${ }^{81}$

"Flat-time sentencing" proposals are criticized in the Report as throwbacks to nineteenth century concepts. Such sentences would reduce most judicial and administrative discretion and return the determination of penalties to legislative control. ${ }^{81}$ The Task Force concludes that neither flat-time or mandatory minimums provide effective responses to current sentencing problems and that some flexibility should be retained.$^{82}$ This flexibility would involve a finding of guilt predictably incurring a particular sentence unless specific mitigating or aggravated factors are present. ${ }^{83}$ The legislature would define the sentencing factors and establish the sentencing parameters, thus leaving release authorities with limited discretion. ${ }^{84}$

The Task Force further urges a considerable reduction in the length of authorized sentences. ${ }^{85}$ Finally, it suggests that more criminal defendants, principally those convicted of serious crimes, serve some time in prison rather than receive probation or a suspended sentence. "If a larger number of serious criminals serve prison terms that are shorter than those served today, we believe that both the justice and the effectiveness of our sentencing system would be significantly increased." ${ }^{66}$

The Committee for the Study of Incarceration, another prestigious group, appears to agree with the position taken by the Twentieth Century Fund Task Force. $^{87}$ It calls for stringent limitations on incarceration as punishment, so

77. Id. at 365 .

78. Twenteth Century fund Task Force on Criminal Sentencing, fair and Certain Punishment (1976).

79. $I d$. at 9 .

80. Id. at $8-9$.

81. Id. at 16 .

82. Id. at 17-18.

83. Id. at 19 .

84. Id. at $19-25$.

85. Id. at 31 .

86. Id. at 32 .

87. A. Hirsch, Doing Justice (1976). 
that only serious offenses would result in imprisonment, ${ }^{88}$ and then for relatively short periods of time. ${ }^{89}$ Alternatives to incarceration would be used for less serious crimes, not as rehabilitative measures, but as less severe punishment. $^{90}$ First offenders would have sharply reduced sentences. ${ }^{91}$ Punishment would be geared to the offense and the criminal history of the offender. ${ }^{92}$ Judicial discretion would be restricted and indeterminate sentencing abolished. ${ }^{93}$ Sentencing guidelines would limit discretion to cases where aggravating or mitigating circumstances were present. ${ }^{94}$

Another influential analysis of our approach to crime, James Wilson's Thinking About Crime, emphasizes the importance of preventing serious crime ${ }^{95}$ Its basic finding is that most serious crime (street crime) is committed by a small minority of repeaters and that judges place many, perhaps most, of these offenders on probation even though they have prior conviction records. The study criticizes sentencing practices based on the immediate problems and idiosyncratic attitudes of judges. ${ }^{96}$ It also points to conflicting evidence on the success of probation and refers to Robert Martinson's conclusion that prisons have failed to rehabilitate most offenders. ${ }^{97}$

Wilson cites studies to show that certainty of punishment has a greater deterrent effect than severity of punishment. ${ }^{98}$ He believes we have become so preoccupied with causes of crime that we have persuaded ourselves "that criminals are radically different from ordinary people-that they are utterly indifferent to the costs and rewards of their activities, and are responding only to deep passions, fleeting impulses, or uncontrollable social forces." 99 His conclusion is that increasing the certainty of a sentence is valuable for its deterrent and incapacitative effects. ${ }^{100}$

Wilson recommends a five-step approach: 1) "[T]he court system should be organized around the primary task of sentencing;" 2) "[T]he sentencing process should be placed under central management, with uniform standards";

\footnotetext{
88. Id. at 110,114 .

89. Id. at 113 .

90. Id. at $118-119$.

91. Id. at 140 .

92. Id. at 133 .

93. Id. at $139-40$.
}

94. Id. at 132. The Committee found to its surprise that it was returning to Beccaria's ideas that punishment should be proportioned to the offense and that discretion should be limited. It rejected the rehabilitative ideal, predictive restraint, and individualization of justice. See id. at 6 , $44,55,99,107-17$.

95. J. Wilson, Thinking About Crime (1975).

96. Id. at $166,179-80$. "Penalties would be primarily designed to fit the crime, with some (but not much) range for judicial discretion in order that mitigating and exacerbating circumstances might be taken into account." $I d$. at 180 .

97. Id. at 169 .

98. Id. at 174 .

99. Id. at 175 .

100. Id. at 177-78. 
3) Every conviction for a non-trivial offense should involve some deprivation of liberty, however brief-only serious offenses should carry lengthy penalties; 4) Deprivation of liberty should not necessarily mean confinement in a conventional prison but could include many options involving potential community-based programs, and conventional probation should be "virtually abolished" for non-trivial offenses; and 5) Conviction for subsequent offenses should "invariably result in an increased deprivation of liberty" depending on the nature of the subsequent crimes. ${ }^{101}$

Still another study, containing a sophisticated analysis of crime and punishment, observes that principles of punishment, charity, and justice may not always coalesce. ${ }^{112}$ Retribution must be inflicted on the guilty according to the severity of their crime. The preservation of the social order may require the subordination of charity, even of justice, in order to punish severely those who endanger society. ${ }^{113}$

The author of this study, Ernest van den Haag, asserts that threats of punishment are credible only if carried out when violations occur. Uncertain or improbable punishment may be directly related to increases in crime. ${ }^{104}$ Moreover, the deterrent effect of certain punishment may extend to lawabiding citizens who would otherwise place little credence in the system. ${ }^{105}$ Necessary reforms, according to $\mathrm{Haag}$, include increasing clearance and conviction rates for crimes, prohibiting probation for subsequent convictions, and minimizing parole for second or subsequent convictions. ${ }^{106}$ Haag appears to agree with Wilson's analysis that most serious crime is committed by a minority of repeaters. ${ }^{107}$

Haag defines those groups among the guilty who should go to prison: 1) serious offenders whose crime is odious in the public eye. The term should be relatively short (2 years) except for those found dangerous, and upon release a system of fines should be imposed; 2) those originally sentenced to fines who wilfully fail to meet their obligations; and 3) those who are dangers to society. ${ }^{118}$

Norval Morris, in his major analysis of the problem, criticizes flat or definite sentences on the ground that there is room for clemency without discrimination and discretion without the abuse of power. ${ }^{119}$ He recommends that certain criteria be adopted by judges as guides in their sentencing decisions. These are: 1) the least restrictive sanction necessary to achieve the sen-

101. Id. at 179-80

102. E. van den HaAG, Punishing Criminals 34 (1975).

103. Id. at 50 .

104. Id. at 14-15.

105. Id. at $22-23$.

106. Id. at 177 .

107. Id. at 162-63.

108. Id. at 241-42.

109. N. Morris, THE Future of IMPrisonment 30 (1974). 
tencing purpose; 2) rejection of dangerousness as an unjust basis for determining imprisonment; and 3) the appropriate sanction "deserved" by the last crime or series of crimes for which the offender is being sentenced. ${ }^{110}$

Obviously the approaches discussed in this section generally both sharply curtail judicial and parole board discretion, and reflect a distrust in the rehabilitative ideal and dangerousness as bases upon which to predict future behavior.

\section{Probation and Parole}

Probation and parole are debated for much the same reasons as indeterminate sentencing. Probation may detract from the certainty and severity of punishment. Parole also detracts from certainty but may add to or detract from the severity of punishment. In the end neither may constitute the fairest treatment of the offender.

The American Bar Association (ABA) in 1970 called for a presumption in favor of a sentence to probation on the grounds that it maximized liberty, vindicated the authority of the law, and effectively protected the public from further violations. The ABA argued that probation promotes the rehabilitation of the offender while avoiding "the negative and frequently stultifying effects of confinement." 111 In support of its position the ABA cited documentation indicating that those put on probation have a generally low rate of recidivism. ${ }^{112}$

A recent study conducted by the General Accounting Office examined a sampling of jurisdictions in the United States. ${ }^{13}$ It found the probation system overburdened, with insufficient sentencing alternatives such as community-based facilities, halfway houses, and regional jails. ${ }^{14}$ It called for the development of guidelines and minimum standards for probation departments, improved sentencing standards for judges, improved information systems, evaluation and accountability of programs, more reliable statistics, and more money. ${ }^{15}$ It concluded that state and county probation systems are not now adequately protecting the public and that most probationers do not successfully complete probation. ${ }^{116}$ In sum, the report approved of adequately financed probation and other community alternatives and called for federal

110. Id. at 58-60.

111. Aba Project on Standards for Criminal Justice, Standards Relating to Probation $\$ 1.2$ (App. Draft 1970).

112 . Id. at 29.

113. Law Enforcement Assistance Administration. Department of Justice, State and County Probation: Systems in Crisis, Report to the Congress by the Comptroller General OF THE UNITED States (1976).

114. Id. at 74 .

115. Id. at 74-75.

116. Id. at 74 . 
help in providing leadership, funds, and technical assistance. ${ }^{117}$

Norval Morris urges that a sharper distinction be drawn between the purposes of incarceration and the opportunities for training and assistance of prisoners that may be pursued within those purposes. "The system is corrupted when we fail to preserve this distinction, and this failure pervades the world's prison programs."118 Morris believes that length of sentence should not be conditioned on apparent response to prison treatment programs, and cites two flaws in the treatment model: 1) the empirical defect of predicting likelihood of criminal behavior in the community by observing prisoner response to prison training programs; and 2) the fallacy that psychological change can be coerced. Prisoners may present the façade of being involved in their rehabilitation because of the indefiniteness of release and the fact that the release date may depend on this facade. ${ }^{19}$ Morris ambivalently cites the parole contract system whereby inmates agree in writing to complete a specific program of institutional activities. Release then becomes contingent upon the inmate's completion of the agreed upon plan. ${ }^{20}$

Morris argues that one way to break the link between release on parole and involvement in prison programs is to establish a release date and disclose it to the prisoner shortly after his incarceration. ${ }^{121}$ He notes that only three factors in the lives of inmates during imprisonment have been correlated with later conformity to the conditions of parole and avoidance of further crime. These factors are the availability of a family or supportive group for the offender to join on release, availability of a supportive job, and the process and duration of aging itself. Morris believes that these are unrelated to treatment aspects of prison programs. ${ }^{122}$

According to Morris, after the release date is fixed independent of program participation, it would be unjust to detain an inmate in prison beyond the release date on predictions of likely future dangerousness. ${ }^{123}$ In lieu of parole he opts for allowing prisoners gradually to make contacts in the community through furloughs, day release programs for work or school, and pre-release guidance centers. ${ }^{124}$

Another recent study, this one conducted by David T. Stanley, concludes

117. Id. at 76

118. N. Morris, supra note 109, at 15.

119. Id. at $15-17$.

120. Id. He questions their chances of success because they may be inherently coercive, $44-45$ But he advocates their use in prisons for repetitively violent criminals, 91, 96-97. See R. EPSTEIN, S. Laty, D. Leonard, \& A. Reiman, The legal Aspects of Mutual agreement Programming in a Correctional System (1976). This publication stems from the Parole-Corrections Project of the American Correctional Association.

121. N. Morris, supra note 118 , at 35.

122. Id. at $35-36$.

123. Id. at 41 .

124. Id. at 41-42. 
that parole boards attempt to do the impossible, namely, predict the behavior of human beings. ${ }^{125}$ Moreover, parole boards base decisions on the invalid assumption that prison training and therapy are effective. Finally, they act unjustly when they refuse release on the grounds that the candidate may commit further offenses after release. ${ }^{126}$

Stanley recommends that standard penalties be specified for each crime, and that judicial discretion be limited to modest variations of the standard penalties. All offenders would serve the full sentence imposed; parole would be abolished. Earlier release for extraordinary reasons could be accomplished by pardon. Under this approach the major rationale for imprisonment would be appropriate punishment. ${ }^{127}$

The other purposes of incarceration are ethically wrong or not practical to implement. Deterrence is a valid objective, but data on the deterrent effect of prison terms are inconclusive, and this goal cannot stand alone. Incapacitation involves predictive restraint, a policy to be avoided on grounds of fairness. Rehabilitation within the correctional system is a myth. The principle of fair punishment, however, is generally recognized in our society as valid and practical. Relying on it as the primary basis for imprisonment should make sentencing judgments less difficult and more consistent.

\section{Individualized Treatment}

Most of the new codes, principles, and model acts mention, if not stress, the need to bring the community to the prison, provide extensive contacts for prisoners with the community, and place prisoners in the community in a variety of structured and unstructured environments. This approach not only contrasts with the early nineteenth century stress on complete separation of the offender from the infectious vices of society, but it is also a departure from those studies in the 1930 s and 1940 s which emphasized reformation of each offender as an individual problem.

Negley K. Teeters, an authority on the American penal system, believes that the principles adopted in 1870 anticipated to a great extent the penology of the 1930s which introduced the concepts of diagnosis, classification, and specialized personnel, including psychologists and psychiatrists, in the attempt to individualize treatment. In Teeters' opinion this approach failed in part because the prison system was still dominated by the nineteenth century faith in the corrective power of monotony and repression; thus the new principles were never completely put into practice. ${ }^{128}$

125. D. Stanley, Prisoners Among Us: The Problem of Parole 185 (1976). See also K.

Davis, Discretionary Justice (1969) for a discussion of parole board discretion.

126. D. Stanley, supra note 125 .

127. Id.

128. N. Teeters, State of Prisons in the United States: $1870-1970$, Federal Probation $18(1970)$ 
Another authority, Lloyd Ohlin, has described the preoccupation of the 1930s and 1940s with the problems of the individual offender as having ${ }^{29}$

led to almost exclusive reliance on the theoretical assumptions and treatment programs of psychology and psychiatry. The clinical model of individual theory has become the primary resource for treatment in our correctional institutions. Even group therapy treatments are oriented primarily toward changing the personality of the individual offenders involved. Certainly many useful insights and effective forms of treatment have arisen through this tendency to individualize the treatment program. Nevertheless this type of treatment is introduced without regard to its relation to the social context within which it operates. A prison is not a collection of unrelated individuals. It is a highly organized system of roles, relationships, rules and activities. The treatment preoccupation with individual offenders has obscured the heavy impact of the prison organization on offenders, not as members of a social system.

Ohlin's interpretation was foreshadowed in the findings of the 1960 Chatham Conference on Mental Health Applications in Correctional Practice, which focused on the need to cure prisoners and stressed personality patterns, behavior modification, attitudinal changes, group counseling, group and individual psychotherapy, and the creation of a healthy emotional climate within the institution. ${ }^{130}$ The following themes dominated the conference: the need for indeterminate sentencing, the desirability of environmental manipulation within the prison walls, the similarity between mental hospitals and correctional institutions, and the reality of severe mental problems which behavioral scientists would help alleviate.

Two years after the Chatham Conference the 1962 Model Penal Code spelled out a number of general principles governing the sentencing and treatment of offenders, among them the need to "differentiate among offenders with a view to a just individualization in their treatment."131 This was a position consistent with the predominant approach of the time.

As already mentioned, the preoccupation with the individual in prison has now given way to a reassessment of the societal factors enunciated by Ferri concerning society and crime causation. The community's role in corrections was articulated by the President's Crime Commission of the mid-1960s. ${ }^{132}$

129. L. Ohlin, Targets for Change in Correctional Institutions, Mobilizing Resources Toward the Rehabilitation of the Offender 51-52 Proceedings of the Saratoga Conference 13-14 (March 19-2 1, 1963) (Sponsored by the New York State Department of Mental Hygiene and U.S. Public Health Service, National Institute of Mental Health.)

130. The Chatham Conference on Mental Health Applications in Correctional Practice, June 1-3, 1960. (Sponsored by Boston University; Massachusetts Department of Correction; Massachusetts Department of Mental Health; and National Institute of Mental Health, U.S. Public Health Service.)

131. Model Penal Code $\$ 1.02(2)(e)$ (Prop. Official Draft 1962).

132. President's Commin on Law Enforcement and Administration of Justice, Task Force Report: Corrections 7 (1967). 
The task of corrections . . includes building or rebuilding solid ties between offender and community, integrating or reintegrating the offender into community life-restoring family ties, obtaining employment and education, securing in the larger sense a place for the offender in the routine functioning of society. This requires not only efforts directed towards changing the individual offenders, which has been almost the exclusive focus of rehabilitation, but also mobilization and change of the community and its institutions. And these efforts must be undertaken without giving up the important control and deterrent role of corrections, particularly as applied to dangerous offenders.

The National Advisory Commission on Criminal Justice Standards and Goals reiterated the important role of the community in correctional programming. ${ }^{133}$

[C]orrections must be linked to the community in every phase of operations. These links are hard to forge because correctional agencies of all kinds traditionally have maintained an isolation from other human service agencies . . Community based correctional programs embrace any activity in the community directly addressed to the offender and aimed at helping him to become a law-abiding citizen. . . It already seems clear that substantial numbers of offenders can be treated in the community safely, effectively, and at substantially lowered cost to the taxpayer....

\section{III}

\section{Prison UNREST}

The history of the American penal system has been punctuated by frequent periods of prison unrest and riots. As early as 1774 there were riots and mass escapes in the Simsbury, Connecticut, copper mine prison. The Walnut Street Jail in Philadelphia experienced riots between 1790 and 1885 . Riots were not unknown in the early prisons of Maine and Massachusetts, and a wave of riots occurred during the years 1929-1932. Between 1950 and 1956 almost one hundred riots and serious disturbances swept the nation's prisons-a dozen on the average every year. ${ }^{134}$

Various factors have been cited to explain this phenomenon, including general social unrest, the intransigence of a few hardened criminals (the "bad apple" theory), and newspaper reports and radio bulletins (the "mass contagion" theory).

In the early 1950s an American Prison Association (APA) study found some of the immediate causes of prison disturbances to be bad food, poor equipment, mistreatment of prisoners, untrained employees, and inept and inexperienced management. ${ }^{135}$ It listed a number of factors contributing to

133. Nat'l Advisory Comm'n on Criminal Justice Standards and Goals, Corrections 221. 222, 227 (1973). Despite the emphasis on community corrections, most new prisons have been built substantial distances from the metropolitan areas from which most offenders come. See W. Nagel, The New Red Barn 46-55 (1973).

134. H. Barnes \& N. Teeters, New Horizons in Criminology 383 (3rd ed. 1959).

135. Comm'n on Riots, American Prison Ass's, Prison Riots and Disturbances 7-14 (1953). 
prison mismanagement, apparently considered by the study to be at the heart of prison unrest. These were categorized under the following headings. ${ }^{136}$
A. Inadequate financial support, and official and public indifference.
B. Sub-standard personnel.
C. Enforced idleness.
D. Lack of professional leadership and professional programs.
E. Excess of size and overcrowding of institutions.
F. Political domination and motivation of management.
G. Unwise sentencing and parole practices.

One critic later accused the ACA study of resorting to the sterile rhetoric of blaming politicians and an indifferent public. ${ }^{137}$

During the 1960s American prisons again suffered a series of riots culminating this time in Attica. A commission appointed to study Attica concluded that the problem of Attica will never be solved "if we focus only upon the prisons themselves and ignore what the inmates have gone through before they arrive at Attica." 138 The Commission cited the criminal justice system as being as much a part of the problem of Attica as the correctional facility itself. ${ }^{139}$

\begin{abstract}
The process of criminal justice will never fulfill either its promises or its obligations until the entire judicial system is purged of racism and is restructured to eliminate the strained and dishonest scenes now played out daily in our courtrooms. Justice is sacrificed to administrative efficiency and there are no winners. Experiences with the inequities of bail, with plea bargaining, adjournments, overworked defense attorneys, interminable pre-sentence delays and disparities in sentences imposed for identical offenses leave those who are convicted with a deep sense of disgust and betrayal. If the criminal justice system fails to dispense and impose punishment fairly, equally, and swiftly, there can be little hope of rehabilitating the defendant after he is processed through that system and deposited in a prison-even a prison remodeled on the principles enunciated above.
\end{abstract}

The principles mentioned in the last sentence actually comprised seven recommendations: 1) retention of all rights except liberty of person; 2) the least confinement necessary; 3) maximum amount of freedom consistent with the security of the institution and the well-being of all inmates in prisons smaller than the typical nineteenth century fortress prisons with over two thousand inmates; 4) close contact with community groups and outside professionals, and public understanding and support; 5) trained correctional personnel equipped to deal with the new breed of young inmates from urban ghettos in accordance with the recognition that the central dynamic of prison life is the relationship between inmates and officers; 6) vocational training and educational programs, and standard pay for services rendered; and 7)

136. Id. at 7 .

137. Fraser, Book Review, 33 Prison J. 23, 24 (1953).

138. New York State Special Comm'n on Attica, supra note 41 , at $\times 1 X$.

139. Id. at 19 . 
parole governed by clear standards disseminated in advance to inmates, who must be told promptly if they are granted parole and if not, why not. ${ }^{140}$

The Commission concluded that although dramatic changes inside prison walls would not cure the evils of the criminal justice system or of society at large, they could do a great deal to alleviate the problems currently facing the penal system.

The riots in American prisons were to some extent paralleled by urban riots during the decade of the sixties. The response was the appointment of the National Advisory Commission on Civil Disorders to examine the causes of these disorders. The Commission profile indicated that most rioters were black males between the ages of fifteen and twenty-five. More than 20 per cent of all the rioters were unemployed; and those who did work held intermittent, unskilled, and low-status jobs. ${ }^{21}$ This profile appears remarkably similar to the profile of prison inmates. ${ }^{142}$

The Commission recommendations provided an agenda for the nation which called for the reordering of national priorities, including a commitment to national action which would require increased taxation. Emphasis was placed on expanding opportunities and eliminating the discriminatory barriers that confront minority groups. Specific recommendations were made in the areas of employment, education, welfare reform, and housing. In addition, a comprehensive national manpower and economic growth policy was urged to fight underemployment and unemployment, the two most persistent and serious grievances of disadvantaged minorities. Finally, the Commission said that schools had failed to provide minorities, particularly ghetto children with an educational background which could help them overcome the effects of discrimination and deprivation. It cited this failure as one of the persistent sources of grievance and resentment within the black community and pointed to the fact that the typical riot participant was a high school dropout. ${ }^{143}$

140. Id. at $16-19$.

141. Report of the Nat'l Advisory Comm'n on Civil. Disorders 73-75 (1968).

142. Nat'l Criminal Justice Information and Statistical Service, U.S. Dep't of Justice, Survey of Inmates of State Correctional Facilities 1974, at 1-6 (Advance Rep. 1976). The survery found that blacks. who represent 11 per cent of the United States population, constituted 47 per cent of the prison population. Three-fourths of the prisoners were $18-34$ years of age and 30 per cent were in the 20-24 age group. The median age for all prisoners was 27 years. For those who held full-time jobs prior to their arrest the median annual income was $\$ 4,639$. About two out of three inmates in this survey had been employed, most of them full-time prior to arrest. About 61 per cent of the prisoners over 18 years of age had terminated formal schooling before receiving a high school diploma.

143. Report of The Nat'l Advisory Comm'n on Civil Disorders, supra note 141, at 229-65. A quite different approach was recommended by criminologist Marvin E. Wolfgang, who spoke of subcultures of violence existing in the cities and generated from the value system associated with the poor, the deprived, and the residents of segregated areas. To him the resort to violence was a sign of despair and failure of an alternative means of expression. The solution is to "disperse the subculture's members thus eliminating the subcultural set of values attached to the use of violence. The form of this dispersal is subsidized relocation and redistribution of the popula- 
In testimony before the Commission, Kenneth B. Clark, a well-known black psychologist, cited previous riots and expressed frustration over the continued inaction.

I read that report-of the 1919 riot in Chicago, and it is as if I were reading the report of the investigating committee on the Harlem Riot of '35, the report of the investigating committee on the Harlem Riot of '43, the report for the McCone Commission on the Watts Riot. I must again in candor say to you members of this Commission-it is a kind of Alice in Wonderland-with the same moving picture re-shown over and over again, the same analysis, the same recommendations, and that same inaction. ${ }^{144}$

\section{IV}

\section{The Prison Environment}

In recent years considerable attention has been directed toward prison architecture as another manifestation of the prevailing penal philosophy. One investigating team looked at over one hundred new prisons and jails built in the last decade to determine whether imaginative and innovative architecture has succeeded in its attempt to make the fact of confinement less obvious. ${ }^{145}$ They found ornamental grills and hollow blocks instead of bars, glazing of internal walls, winding paths replacing long bleak corridors, and landscaped lawns and gardens. A college-trained staff hustled at important tasks of supervising, teaching, counseling, training, treating, and disciplining. However, this team still observed the old preoccupation with control. William Nagel writes of the group's observations: ${ }^{146}$

We also observed deep mutual suspicion, great cynicism and pervasive hypocrisy as the kept and the keepers played old games with each other while using the new sophisticated language of today's behavior scientists. I have not worked in a prison since 1960 but it was as if everything had changed, yet nothing had changed. The institutions were new and shiny, yet in all their new finery they still seemed to harden everyone in them. More people enter the system wanting desperately to change it, but the problems they find are so enormous and the tasks so insurmountable that these warm people turn cold.

tion." To break up the subculure, you must spread the members into other subcultures where violence is not a dominant way of life. Wolfgang, Violence U.S.A., 14 Crime and Delinquency 289, 299-300 (1968).

144. Report of The Natl Adisory Comin on Civil Disorders, supra note 14l, at 265 (testimony of Kenneth B. Clark).

145. W. NAGEL, supra note 133, at 1-3.

146. Id. at 147-48. These findings are paralleled in a simulated jail experiment conducted at Stanford University. Using students as jailors and inmates, and replicating actual jail conditions, the experiment found that encounters between inmates and custodians "tended to be negative, hostile, affrontive and dehumanizing." The experiment was terminated prematurely, after six days. Student inmates were delighted. Student guards were distressed. It appeared they had become sufficienty involved in their roles so that they "enjoyed the extreme control and power which they exercised and were reluctant to give it up." C. Harney, C. Banks, P. Zimbardo, Interpersonal Dynamics in a Simulated Prison (unpublished and undated manuscript on file at Institute of Criminal Law, 605 G St., N.W.. Wash. D.C. 20001). 
In time they can no longer allow themselves to feel, to love, to care. To survive, they must become callous. The prison experience is corrosive for those who guard and for those who are guarded. This reality is not essentially the product of good or bad architecture. It is the inevitable product of a process that holds troubled people together in a close and limited space, depriving them of their freedom, their families, and their humanity while expecting a relatively few employees to guard, control, punish, and redeem them.

Nagel calls for a halt in the construction of new prisons, jails, and training schools while alternatives are developed. As long as we build, according to Nagel, neither the pressure nor the will to develop more productive answers will arise. ${ }^{147}$ Prisons provide only the illusion, not the reality of protection against the criminal-they merely sweep the criminal and the problem under the rug. Nagel's remedies are the familiar alternatives to incarceration and a reordering of national priorities.

The question of whether or not there should be a moratorium on construction while alternatives are explored and expanded, and just what direction corrections should take has been debated strenuously for a number of years. The issues were sharply delineated at the 1973 annual ABA meeting. ${ }^{148}$ Milton Rector, President of the National Council of Crime and Delinquency (NCCD), reiterated the NCCD position favoring a moratorium on the building of new prisons and jails. ${ }^{149} \mathrm{He}$ argued that prisons currently have neither a rehabilitative nor a deterrent effect on most people intent on committing a crime. Only assaultive and dangerous criminals should be imprisoned and, meanwhile, alternatives to incarceration should be rapidly expanded.

Peter Bensinger, former Illinois Commissioner of Corrections, said at the ABA meeting that prison should serve both to protect the community and to rehabilitate the offender. He agreed with Rector on the need for community involvement, probation, work release, and detailed system-wide planning. But he cited the nineteenth century institutions, usually located in rural areas, which characterize the current prison system, and argued that new prisons should not be mere replacements but community correction centers guided by alternative approaches to treatment. ${ }^{150}$

We need new management methods to manage confinement facilities. We need the availability of community resources and realistic staff development and minority recruitment. But above all we need to break up the mega-prison complexes. Where present facilities do not meet minimum human care and/or safety standards we need to move ahead to develop new and long needed adequate security resources. To do less is to deny the law which we have written. To do less is to face the physical violence and the consequences of what we still have in our state systems.

147. W. NAGEL, supra note 133, at 148-57.

148. ABA Section of Criminal Justice, New Directions for Corrections? (1973).

149. Id. at 4-8. The NCCD position is found in Nat'l Council on Crime and Delinguency,

Policies and Background Information on Institutional Construction (1972).

150. New Directions for Corrections?, supra note 148 , at 10. 
John Boone, former Massachusetts Commissioner of Corrections, expressed his belief that prisons function at least partly to symbolize society's failure, citing as causes of that failure inadequate schools, social services, and mental health programs. Claiming that the high cost of prison is a result of bad political, social, and economic practices, Boone advised using containment money to help most prisoners function in the community and to focus on the quality of services, jobs, and supportive social programs. Like Rector, he envisioned a system in which only dangerous individuals would have to be incarcerated. ${ }^{151}$

$\mathrm{V}$

\section{The High Cost of Prison}

The issues discussed at the 1973 ABA meeting are, of course, closely tied to the economics of corrections. What to do about our prisons and how to allocate resources are questions that must be considered in light of the costs of construction and programs.

The NCCD estimates that it will take billions of dollars to build new prisons and jails and that many of the present structures will be enlarged rather than replaced. The operating costs of the existing system are projected to rise dramatically in the next four years. ${ }^{152}$ By 1980, assuming no change in policies or prison population, the annual operating costs (excluding construction costs) will approximate three billion dollars in the United States for all prisons (excluding jails). If the average length of time served is doubled, the cost will exceed six billion dollars by 1980 . Finally, if the rate of increase in the quality and scope of prison services is doubled, the costs will rise to over twenty billion dollars by 1980 .

Another way of looking at correctional expenditures is to compare the apportionment between prison and jail personnel and probation and parole personnel. One study revealed that 75 per cent of correctional personnel were involved in institutions and 25 per cent in probation and parole. It also found that institutional personnel received extraordinarily low salaries, and that almost all top administrators, first line supervisors, and functional specialists such as psychologists, were white. Only in the juvenile field was this pattern broken, and even there almost 80 per cent of the personnel force was white. ${ }^{153}$

A detailed analysis of correctional expenditures for the year 1974 indicates heavy emphasis on institutional expenditures. ${ }^{154}$ Direct current expenditures

151. Id. at 111 .

152. Congressional Research Service, library of Congress, Prison Population and Costs-Illustrative. Projections to 1980 at 2-3 (1974).

153. Joint Comm'n on Correctional Manpower and Training: A Time to Act 11 (1969).

154. U.S. Dep'ts of Justice \& Commerce, Expenditures and Employment Data for the Criminal Justice System 1974 (1976). 
for corrections activities of state governments in that year involved little over $\$ 1.5$ billion, of which only about $\$ 229$ million was for probation and parole. Of almost $\$ 700$ million spent in large counties, two-thirds was for institutions and one-third for probation and parole. Finally, in large cities almost all of the $\$ 283$ million expenditure was for institutions. ${ }^{155}$

The prison population in the country has increased markedly in the last few years. According to Richard W. Velde of the Law Enforcement Assistance Administration (LEAA), between January 1, 1973 and January 1, 1975 the United States prison population jumped 11.3 per cent from 196,092 to $218,205 .{ }^{156}$ The crisis resulting from this growth was highlighted recently when the LEAA loaned 475 trailers (originally used to house victims of a 1972 flood) to ten states to alleviate prison overcrowding. The LEAA indicated that the population problem had become so grave that "innovative correctional officials are resorting to tents in Florida and a Salvation Army hostel in Michigan." ${ }^{57}$ It also cited the use of former mental hospitals, tuberculosis treatment centers, and even converted airplane hangars.

Velde pointed to other LEAA efforts in making grants to states to buy mobile trailers. A project alleged to be creative was under way in Virginia, where fifty-six trailers provided by LEAA will result in the operation of what might be the nation's first "Trailer Park Correctional Center." ${ }^{58}$ The plan calls for trailers, mostly sixty-five feet by twelve feet, to be built into six modules of eight trailers each. The trailers will open into a center core building constructed of cinder blocks. Six trailers on each module will be sleeping units housing twelve men each, and two trailers will be recreational vehicles containing lounges with television sets and ping-pong and pool tables. Eight other trailers will be used for administrative purposes. A guard in a control booth in the core area will be able to look over the trailers. ${ }^{159}$

155. Id. at 270, Table 40; id. at 277, Table 42; id. at 290, Table 44

156. See LEAA News Release 3 (Sept. 4, 1976). Sherman R. Day, Director of the National Institute of Corrections, stated that during 1975 the number of inmates rose 11 per cent-from 225 thousand to 249 thousand. He attributed this to the continuous rise in serious crime, about 17 per cent in 1974, another 10 per cent in 1975, and further growth in 1976-and the maturation of World War II baby boom children. Address by Sherman R. Day, 16th Annual Kentucky Council on Crime and Delinquency Convention, reported in 7 Corrections Digest No. 19, at 1 (1976).

157. LEAA News Release 2 (Sept. 4, 1976)

158. Id. at 1 .

159. The description makes it appear similar to the "Panopticon" of Jeremy Bentham, planned and almost built near the end of the eighteenth century. It would have looked like a huge tank, covered by a glass roof, with cells on the outer circumference, facing the center, and an apartment for the keepers in the center. Thus all cells could be kept under scrutiny. H. Barnes \& N. TeETERs, supra note 134 , at 335 . One large panopticon prison was built in Statesville, Illinois, in 1909. For pictures of the institution, see W. NAGEL, supra note 133, at 38 . It more likely will look like the Eastern State Penitentiary, Philadelphia, Pa., built in 1829 . There were seven outside cell blocks radiating from a common center like the spokes of a wheel. See D. Rothman, ThE Disovery of THE ASYlum 98 (1971) for an illustration of this prison. 
The problems of overcrowding are compounded by the heavy and rapidly increasing costs of building new institutions. One analysis estimated individual inmate per bed costs of $\$ 41,014$ for high security institutions, $\$ 31,470$ for mixed security institutions, and $\$ 27,343$ for jails. ${ }^{160}$ This 1976 report also pointed out that financing these institutions by issuing bonds would add substantially to these costs-the annual capital cost per bed would be $\$ 3,712$ for high security institutions, $\$ 2,848$ for mixed security institutions, and $\$ 2,734$ for jails.

Those calling for a moratorium on the construction of new jails and prisons cite such figures to support the contention that little money would be available for alternative programs should construction of new institutions become the high priority expenditure. They argue that violence in prisons may be a natural corollary of the prison environment, and that new programs, not new prisons, will solve the crime problem.

\section{VI}

\section{An Emerging Consensus?}

Few authorities in the field believe that our corrections system has been successful. The record on rehabilitation, humaneness, and fairness is dismal. Analyses of the problem are as divergent as the preconceptions and ideologies on which they rest. The last few years, however, have seen a serious rethinking of the problem. Suggested approaches cover the sentencing and release of convicted individuals and the role of corrections in the criminal justice system. Most of these approaches reflect a distrust in our ability to make decisions about others on the basis of existing knowledge of human nature.

In his important work Thinking About Crime, James Wilson argues that if the existing correctional system does not meet our goal of rehabilitation, we must question the purpose of incarcerating offenders. ${ }^{161}$ Obviously we cannot free them. Therefore, according to this analysis, the function of the correctional system should be to isolate and punish, in recognition of the fact that society must at a minimum protect itself from dangerous offenders. If much or most serious crime is committed by repeaters, as Wilson claims, then separating them from the rest of society, even for brief periods of time, may significantly reduce crime rates. ${ }^{162}$

Another major analysis of the failures of our correctional system, this one by David Fogel, concludes that there appears to be an emerging consensus in the field. ${ }^{163}$ The elements of this consensus are: 1) Sentencing criteria should

160. Nat'l Institute of Law Enforcement and Criminal Justice, Cost Analysis of Correctional Standards: Institutional-Based Programs and Parole 18 (1970).

161. J. Wilson, Thinking About Crime (1975).

162. Id. at $172-73$.

163. D. Fogel, We Are The Living Proof 242-3 (1975). 
be statutorily required. 2) Sentencing should be based on classification of offenders into risk categories. 3) Sentencing should be more definite (there are fairly broad variations but indeterminacy is substantially rejected), or fixed and graduated by seriousness of the offense. 4) Sentences should be reviewable. 5) Sentences of imprisonment should be substantially reduced. 6) Sentences of imprisonment should be justified by the state after an exhaustive review fails to yield a satisfactory community-based sanction.

If a consensus is forming, though, it is not unanimous. Many proposed codes and standards indicate that the rehabilitative ideal and the discretionary authority associated with it is still very much alive. One criminologist, Sol Chaneles, openly rejects attacks on the rehabilitative ideal. ${ }^{164} \mathrm{He}$ argues that easy money is available for prison construction, primarily because business and construction groups have a vested interest in new prisons. He criticizes the modest sum now being spent on rehabilitation programs, pointing out that it amounts to less than "five percent of the $\$ 5$ billion spent annually on prison operation." He concludes: ${ }^{165}$

We should expect more from our correctional system than warehousing. We should expect substantial reductions in recidivism. But that will happen only if rehabilitation resources and opportunities now available to less than $5 \%$ of the inmate population reach the great majority. Certainly no single method of rehabilitation will work for everybody, and we should reject those techniques that don't work while improving and expanding the use of those that do. The bond of humanity between the inmates and those of us on the outside demands no less.

In Fogel's view, the aims described by Chaneles are achievable through different means. According to Fogel, prison should merely represent a deprivation of liberty; the prisoner should choose the programs he wants; and the sentence must be seen as part of a reasonable and constitutional continuum of justice. "It is in the context of justice that a mission arises for the prison and its staff. The mission is fairness." 166 Correctional administrators have operated with immunity from law for too long. Fogel's justice perspective demands accountability. "Properly understood the justice perspective is not so much concerned with administration of justice as it is with the justice of administration."167

Fogel believes that prisoners should have a voice in prison life, and that a program of self-governance should engage in conflict resolution through a formal procedure conducted by a representative body. The premise behind his proposal is that men who can negotiate their fates do not turn to violence as a method of achieving change.

164. Chaneles, Prisoners can be rehabilitated-Now, Psych. Today, Oct. 1976, at 129.

165. Id. at 135 .

166. D. FoGel, supra note 163 , at 202.

167. Id. at 192. 
Fogel is not alone in this call for application of the rule of law to prisons. The American Bar Association established a Joint Committee on the Legal Status of Prisoners several years ago. It has issued a report whose basic assumption is the following: "Prisoners retain all the rights of free citizens except those on which restriction is necessary to assure their orderly confinement or to provide reasonable protection for the rights and physical safety of all members of the prison community."168 A considerable body of literature on the subject of prisoners' rights has appeared in recent years. ${ }^{169}$

\section{VII}

\section{The Future of the Corrections System}

Long accepted assumptions about the nature of our corrections system are currently subject to critical, sometimes savage review. The topic is hotly debated at conferences and meetings all over the country. Individuals who held one view a year ago have now decided to switch rather than fight. But is real change in the offing?

Rick Carlson, in a recent study of the corrections system, suggests a method of determining whether fundamental change is about to occur. ${ }^{170}$

The first [step] is the accumulation of bits of data that don't 'fit.' At first this information is either ignored or discounted, but as the bits increase, they become more difficult to ignore or argue away. At the second stage, because of accumulating information, the old explanations begin to make less sense -serious 'cracks' in the accepted explanations become visible. At about this time-new ideas-new explanations also begin to appear. In this third, transtitional stage, there is not yet any consolidation, but new explanations begin to compete with old ones. Finally, at the fourth step, consensus snaps into view, sometimes suddenly. A new and different way of looking at things emerges, which supplies the explanation for both the new data and the new ideas. .

Are we at any of the above stages? Carlson points out that information undermining the rehabilitation model has been accumulating steadily. New perspectives (or perhaps, according to Carlson, restatements of old ideas) on retribution, punishment, and deterrence have now surfaced-along with increased attention to community-based correctional programs. These new perspectives are competing with the older attitudes for allegiance. Since no critical mass of support has developed for a new, synthesizing theory, Carlson feels we may be at the third, or transitional, stage of change. But Carlson

168. ABA Joint Comm'n on the Legal Status of Prisoners, Tentative Draft of Standards Relating to the Legal Status of Prisoners, 14 AM. CRIM. L. REv. 377, 387 (1977).

169. See H. Hoffman, Prisoners' Rights (1976); H. \& J. Kerper, Legal Rights of the Convicted (1974); S. Krantz, R. Bell, J. Brant, \& M. Magruder, Model Rules and Regulations on Prisoners' Rights and Responsibilities (1973); South Carolina Dep't of Corrections, The Emerging Rights of the Confined (1972); Nat'l Council on Crime and Delinguency, A Model Act for the Protection of Rights of Prisoners (1972).

170. R. Carlson, The Dilemmas of Corrections 9 (1976). 
believes that fundamental change will not occur until a new view of the nature of humanity itself emerges. ${ }^{171}$

At this time of uncertainty and change, it is important that we ask what roles different groups will play in reform efforts, particularly as these efforts relate to changes in sentencing and the development of community facilities and services. Proponents and opponents of the rehabilitative ideal have called for a wide variety of alternatives to conventional imprisonment. But they must do more than that. Mere passage of laws is not enough. ${ }^{172}$ Financial and community support is essential before such facilities and services are even begun.

Citizens in a community are frequently unaware of the real issues involved in decisions as to how offenders are processed and treated. They may support the concept of rehabilitation as expressed, for instance, in halfway houses, but location of such facilities in their community may not receive similar support. ${ }^{173}$

Nonetheless, citizens have become heavily involved in a variety of activities relating to working with juvenile and adult offenders. ${ }^{174}$ Whether or not such heavy involvement has alerted these citizens to the fundamental problems of corrections or given them the ability and will to demand input at the policymaking level is problematic. ${ }^{175}$

The lawyer's role in achieving change has generally been limited to the

171. Id. at 10

172. See H. Miller, Comprehensive Pretrial Release Programs for fairfax County (1973), for what it takes to implement a new Virginia State bail reform act in one county. (Prepared as counsel for the Citizens Comm. on Pretrial Release, Fairfax County Citizens Coalition for Justice).

173. In a survey by Louis Harris and Associates for the Joint Commission on Correctional Manpower and Training, 77 per cent of the public interviewed indicated support for the ideas of halfway houses, yet only 50 per cent would favor such a program in their own neighborhood. Joint Comm'n on Correctional Manpower and Training, The Public looks at Crime and Corrections 2 (1967).

174. See Miller. The Citizen's Role in Changing the Criminal Justice System, 19 CRIME \& Delinquency 343 (1973).

175. The author's experience with a wide variety of citizens' groups working in the courts and correctional areas has been that officials of the criminal justice system welcome citizen participation so long as it involves citizens doing what those who run the system believe is necessary or advisable. The same actors react differently to citizen participation when citizens and the groups they represent seek to influence the making of policy. On the other hand, it has been the author's experience that citizens and the groups they represent are too often willing to go along with members of the criminal justice establishment (lawyers, judges and correctional officials) when strong pleas are made or pressure is exerted. See Hearings on the Community Anticrime Assistance Act of 1973 Before the Subcomm. on Crime of the House Comm. on the Judiciary, 93d Cong., 2d Sess., ser. 49, pt. 2, at 16-24 (1975) (testimony of Herbert S. Miller). Also, see the view of Herbert L. Packer: "The Criminal Sanction . . . raises legal issues that are too important to be left to the lawyers, philosophic issues that are too important to be left to the philosophers, and behavioral science issues that are too important to be left to the behavioral scientists. That is why the argument is addressed with affectionate respect, to the Common Reader." H. Packer, The limits of the Criminal Sanction 5 (1968). 
traditional arenas of the legislature and judicial system. Although some efforts have been made to work directly with inmates eligible for parole, most efforts have involved the structure of laws and procedural requirements under the Constitution. Thus juveniles may be due processed into reformatories and prisoners due processed into isolation. The willingness of lawyers to fight for resources and facilities in the community has not been demonstrated. ${ }^{176}$

What role will judges be expected to play in projected new approaches to sentencing and corrections? On the assumption that judges are no more capable than anyone else of rationally and equitably imposing sentences, many authorities have called for a lessening or abolition of judicial discretion. There is reason to believe, however, that such proposals would not meet with general judicial approval at this time. ${ }^{177}$ The ABA has glorified judicial discretion in its Standards on Sentencing Alternatives and Procedures, standards which do little more than provide the vaguest guidelines to judges. ${ }^{178}$

Finally, what about those who manage and operate our corrections system? And in addition to them, swarms of researchers, therapists, and bureaucrats are sustained by the correctional business. Rick Carlson writes: ${ }^{179}$

\begin{abstract}
None of these people, nor those directly employed in penal work, would be overjoyed if the system were jettisoned. As a result, it is argued, often by offenders and ex-offenders, that the system managers are the real blocks to reform. Any reform that might reduce the size of the system is likely to be opposed. Of course this is true in almost any labor-intensive field-it's what featherbedding is all about. Some proof of the accusation is furnished by recent experience. In 1972, when the Massachusetts State Department of Institutions sought to bulldoze the juvenile detention facilities, nothing could be done until the job of those affected had been secured elsewhere.
\end{abstract}

Carlson feels that crime is deeply embedded in our social structure, and that rather than trying to curb it, we merely regulate it. In this environment real change is an illusory goal. But Carlson is not totally pessimistic. Real change is possible if we alter our current values and become less tolerant of the inequities that prevent real change. He believes that our society is at a cultural watershed-that we are beginning to perceive the inadequacy of the tools and institutions we have created to solve our social and economic problems. ${ }^{180}$

This recognition may lead in turn to the recognition that we have the opportunity and resources to recreate ourselves, and, in turn, our institutions. Cor-

176. See Miller, The Lawyer's Hang-Up: Due Process Versus The Real Issue, 11 Am. Crim. L. Rev. 197 (1972). The ABA Commission on Correctional Facilities and Services has provided some institutional leadership in this area. See ABA Comm'n on Correctional. Facilities and Services, When Society Pronounces Judgment (1975).

177. See Robin, Judicial Resistance to Sentencing Accountability, 21 Crime \& Delinguency 201 (1975).

178. A Ba Project on Standards for Criminal Justice, supra note 50.

179. R. CARLSON, supra note 170 , at 167.

180. Id. at $168-9$. 
rections, and indeed the entire criminal justice process, is a derivative system-it only reflects dominant values. If those values change, our means of dealing with crime will change as well. That is my hope.

It is not easy to be optimistic about the future of our corrections system. As Kenneth Clark indicated, crises are repeatedly followed by studies but little action. ${ }^{181}$ And what action has been taken does not seem to indicate that society is capable of learning from past experience. ${ }^{182}$

Most suggested approaches appear to revolve around the notion that through rehabilitation, punishment, deterrence, the just prison, or mutations or combinations thereof, the correctional system will have some impact on crime. But there is little evidence to this effect. For example, James Wilson argues that putting the small number of repeaters of violent street crime into prison, even for relatively short periods of time, will help solve the crime problem. At best, given high clearance rates of apprehension and conviction, upon release such offenders will probably be just as ill-equipped to cope in a work-oriented society as they were before they went in. The evidence indicates high recidivism rates for such individuals.

Fogel's notion of the just prison is laudable. However, if we follow his and others' prescriptions, prison will be reserved only for the more serious offenders. Relatively nonserious offenders will be placed in some kind of community setting. Thus we can assume that those in prison will represent the hardcore offenders. The emphasis will be on security and control-and it will affect the watched and the watchers. On scant evidence Fogel believes that those who cannot act responsibly in free society will act responsibly in prison. ${ }^{183}$ His notion of a just prison implies responsible participation by the inmates in a purely artificial environment. Even if such an arrangement succeeds, the fact remains that it is an artificial environment with little relationship to the stresses of the free world.

Those who opt for a variety of community facilities and services should reexamine their belief that the less serious offender can be helped to resist the traditional path toward more serious offenses. ${ }^{184}$ At best the evidence is

181. Report of The National Advisory Comm'n on Civil Disorders, supra note 141, at 265 (testimony of Kenneth B. Clark).

182. The reaction to recent violence in Colorado Prisons was a special session of the state legislature. Appropriated was $\$ 1.1$ million, mostly for new construction and modification of prison security devices and towers, and fifty-seven new employees for additional works programs. The rest was for the development of a correctional master plan. Tough legislation was enacted dealing with riots, escapes, searches, and inmate assaults on correctional employees. In Colorado, Special Legislatize Session Funds Corrections System, Passes Tough New Laws 7 Corrections DigesT No. 20, at 3-4 (1976).

183. D. Fogel, supra note 163.

184. ... [s]tudies ... show that the most frequent pattern among adult offenders is one that starts with petty stealing and progresses to much more serious property offenses . . [ [h]omicides, rapes, and robberies were several times more prevalent among the rearrests than among the first 
conflicting as to whether such community facilities and services actually accomplish their goals.

We do not know for certain the causes of crime. Neither do we know if the deeper problems of our society generally, such as its economic and political structure and the allocation of its resources and goods, have any effect on crime. We have our suspicions. Some of us believe that the inequitable distribution of the wealth, and of educational and work opportunities, is a basic cause of some crime. But it is questionable whether society is willing to make the kind of basic decisions which might rectify this situation.

We must ask ourselves whether the primary way to attack crime is through the criminal justice system. This is not to say that we do not need a fair and efficient criminal justice system to protect all citizens and properly punish offenders. We do, and we should fight for it. Nor is this to say that work, training and educational programs should not be made available to offenders in institutions and the community. They should. Finally, realistic community alternatives to incarceration for non-serious offenders should be made available to sentencing authorities and those incarcerated should have an environment compatible with the Constitution and humaneness. But it is a pretense on our part to claim that these efforts are by themselves the most effective way to combat crime. Until we achieve a truly just society-not only a just prison-talk about preventing crime will remain that, just talk.

arrests. President's Comm'n on Law Enforcement and Administration of Justice, the Challenge of Crime in a Free Society 46, 265 (1967). 